\title{
Morphological and Immunohistochemical Stud- ies on the Pineal Gland of the Donkey (Equus asinus).
}

\section{Safwat Ebada}

* Department of anatomy and embryology, Faculty of Veterinary Medicine, Mansoura University, Egypt.

\section{Abstract}

The pineal glands of donkey were light beige to dark brown, fusiform structure. It lies at the pineal recess caudal to the splenium of the corpus callosum and caudodorsal to the third ventricle, just in front of the rostral colliculi and in between the para hippocampal gyrus. The pineal gland was supplied from the caudal choroidal artery and branches from artery of corpus callosum. The venous drainage by the pineal veins flowing into the cerebral vein.

The glial fibrillary acidic protein (GFAP) and S100 protein immunoreactivity was restricted to glial cells. They showed a heterogeneous pattern of immunostaining for (GFAP) and S100. It was conspicuous around the large pineal cyst and corpora arenacea, where the pinealocytes formed clusters, widely separated by aggregations of GFAP and S100 immunoreactive glial cells and their processes. They were also striking around blood vessels. At the periphery of the gland, only a relatively few GFAP and $\mathrm{S} 100$ positive cell bodies and/or processes were seen in the marginal portions of the parenchyma. S100 immunoreactive cells showed similar morphological characteristics to those of GFAP-reactivity, but their immunoreactivity was denser. Immunolabeling of the pinealocyte marker synaptophysin was intense, especially in pinealocytes at perivascular space. Several highly synaptophysin-positive blotch of variable extent were a conspicuous feature in pinealocyte throughout the gland. While it was less dense in 
the vicinity of the pineal cyst and corpora arenacea. The intercellular differences in the degrees of synaptophysin immunostaining may, therefore, reflect different states of a specific cellular activity. The presence of synaptophysin in pinealocytes of the normal pineal, highlights the paraneuronal nature of these cells.

\section{Keywords}

Pineal gland, Immunohistochemistry, Synaptophysin, $\mathbf{S 1 0 0 ,}$ GFAP, Donkey, Equus asinus

\section{Introduction}

The pineal gland is a neuroendocrine tissue regulates changes exclusively in the functions of the endocrine system as well as the functions of many other systems according to light and dark and functions like a biological clock along with supra-chiasmatic nuclei. The pineal gland sends time signals to other parts of the body in circadian rhythm through melatonin hormone. It has an important role, in particular, in control of reproduction functions and in evaluation of seasonal changes in day length (Arendt, 1995; Cagnacci, 1996). Generally, light decreases the production of mel- atonin, whereas darkness increases it (Arendt, 1995). Light impulses are sent to suprachiasmatic nuclei, in hypothalamus, through retinohypothalamic tract where the circadian rhythm of melatonin secretion is regulated. SCN suppresses the melatonin synthesis according to the amount of light (Arendt 1995; Cagnacci 1996). The mammalian pineal gland contains two types of parenchymal cells. The pinealocytes which form the majority of parenchymal cells and responsible for melatonin secretion in the pineal gland. Glial cells serve as supporting cells and they are fewer in number than pinealocytes (Arendt, 1995 and Kus et al., 2004). The literature contains numerous descriptions of pineal gland ultrastructure in rat (Sakai et al., 1996), rabbit (Garcia and Boya, 1992 b), dog (Calvo et al., 1990), horse (Cozzi 1986), cow (Sato et al., 1994), and sheep (Regodon et al., 1998 a \& b). Pinealocytes play a key role in melatonin secretion in response to sympathetic nerve stimuli; this gland may therefore be treated as a neuroendocrine organ. In addition to HIOMT (hydroxyindoleomethyl transferase), which catalyzes the final step of melatonin biosynthesis, some 
neuronal proteins have been detected in pinealocytes, revealing the neuron-like nature of these cells (Coca et al., 1992, Redecker and Bargsten, 1993). Synaptophysin (Huang et al., 1992, Redecker and Bargsten 1993, Sato et al., 1994). S-100 protein and intermediate filament proteins, glial fibrillary acidic protein (GFAP) are known as glial marker proteins in supporting cells of the pineal gland in rat, hamster and human (Lopez-Munoz et al., 1992; Borregon et al., 1993; Boya and Calvo, 1993). However, the use of neuroendocrine cell markers applied to mammalian pinealocytes in general, and a glial marker S-100 protein and intermediate filament proteins (GFAP). Immunoreactivity of these antibodies has not been studied in donkey pineal in the available literature. Our goal was to identify pineal cell types and their distribution in adult donkeys via immunohistochemical method using antisera to neuroendocrine cell marker (synaptophysin), S100 protein and GFAP.

\section{Materials and methods}

\section{Animals and tissue}

Adult, apparently healthy donkeys used in this study were pur- chased locally and maintained under recommended husbandry conditions. The pineal glands were obtained according to the institutional ethical committee of the Mansoura University, Egypt.

\section{Anatomy and Histology}

After sacrificing the animals, the pineal gland was extracted, fixed in bouin's solution for 24 hours, then washed and persevered in $70 \%$ ethanol, the samples were dehydrated in ascending grades of ethanol, cleared in benzene and embedded in paraffin wax. Section $(5 \mu \mathrm{m})$ thickness were stained with iron haematoxylin and eosin (H\&E), PAS, Alcian blue (2.5 PH) and Crossman's trichrome stains. Processing and staining methods were quoted from Bancroft et al. (1996). Three donkey's heads were perfused with a warm normal saline solution, and then injected with an equal mixture of Indian ink and bovine serum (1:1) through the Jugular vein and two heads were injected with colored latex with carmine through the common carotid arteries. The injected specimens were fixed in $10 \%$ neutral formalin buffered solution for 1-2 weeks.

\section{Immunohistochemistry}


Monocolonal mouse anti-human Glial Fibrillary Acidic Protein (GFAP) (M0761; diluted1:50), S100, ready-to-use (N1573; diluted1:50), rabbit anti human Synaptophysin, (N1566; diluted1:100), polyclonal rabbit anticow (Dako Cytomation, Denmark) were used for detection of GFAP, S100 and synaptophysin respectively (Table 1). Section of $(3 \mu \mathrm{m})$ thick mounted on slides precoated with polylysine, deparaffinized, rehydrated, and then incubated for 5 minutes in hydrogen peroxide ( $3 \%$ in distilled water) to reduce endogenous peroxidase activity. The slides were rinsed in phosphate buffer saline solution (PBS 7.4 PH), then subsequently heat treated in microwave at $750 \mathrm{~W}$ for tow cycles of 7 minutes each in citrate buffer (6 $\mathrm{PH}$ ) for antigen retrieval. Thereafter the section were allowed to cool at room temperature for 20 minutes before being rinsed in phosphate buffered saline containing bovine serum albumen (PH 7.6) for 5 minutes to block nonspecific binding sites. Subsequently, the sections were incubated with the specific primary monoclonal antibody for $1 \mathrm{~h}$ in a humidified chamber at room temperature against GFAP and synaptophysin and S100 follow- ing the protocol of LSAB+kit (Dako Cytomation, Denmark). After being rinsed in BPS biotinylated secondary antibody (LASB + Kit; Dako Cytomation, Denmark) was applied to the sections for 30 minutes in humidified chamber at room temperature followed by incubation with peroxidase-labelled streptavidin for 15 minutes. Bound antibodies localization was visualized by incubation of the sections with the 3,3 diaminobenzidine (DAB) of the LSAB+Kit solutions (Dako Cytomation, Denmark). The sections were counterstained with Mayer's haemtoxylin, dehydrated and mounted with DPX (Sigma, Munich, Germany). Negative control performed by omission of the primary antibody. The methods of processing and immunohistochemical staining were adopted after Kumar and Rudbeck (2009).

\section{Results}

\section{Anatomical and Histological findings}

The pineal glands of donkey, were light beige to dark brown in colour and fusiform structure. The pineal gland lies at the midline of the brain at the pineal recess 
caudal to the splenium of the corpus callosum from which it separated by the telachoroidea of the third ventricle, cerebral vein and branches of artery of corpus callosum and caudodorsal to the third ventricle, just in front of the rostral colliculi and in between the hippocampus. Weighting approximately $0.1 \mathrm{gm}$, with an average dimensions, $14 \mathrm{~mm}$ dorsoventral, $7 \mathrm{~mm}$ craniocaudal and 5 $\mathrm{mm}$ thickness. The pineal gland was supplied from the posterior choroidal arteries which emanated from the caudal cerebral arteries, it receives also pineal branches from the artery of corpus callosum that originates from the rostral cerebral artery. The venous drainage by the pineal veins flowing into the cerebral vein (fig. 1)

The adult pineal gland of donkey had a well distinct capsule, from the capsule a small incomplete septa extended into the parenchyma. The glandular parenchyma is composed largely of pinealocytes, these cells is linked to the glial cells in the area surrounding them. The distinction of these cells were made according to the staining features of their nuclei. Pinealocyte were rounded cells with a clear, abundant and acidophilic cytoplasm, and a large round nucleus. Glial cells nuclei were small darkly stained. Calcium concretions (corpora arenacea) and pineal cysts of different size were a constant feature in pineal gland. Pinealocytes occupied the largest volume of the pineal gland. The interstitial cells were distributed evenly throughout the superficial pineal gland, but they were more abundant around the pineal cyst and corpora arenacea. A relatively large blood vessels were observed in the connective tissue capsule, the greater part of blood vessels were found in the trabecules of the connective tissue, blood capillaries were frequent in the connective tissue in between pinealocytes and glial cells (fig. 1).

\section{Immunohistochemical finding}

\section{S100}

A strong anti S100 immunoreactivity was found in the starshaped glial cells and their processes, that were evenly distributed at the pineal gland except at the area of pineal cyst and calcium concretion (corpora aranacia). Star-shaped glial cells and their processes were strongly immunostained with anti-S-100 
protein, they were numerous and densely distributed especially in the periphery of the body portion of the pineal gland, their radially densely stained cytoplasmic processes were seen among pinealocytes, forming a mesh work. S100 immunoreactivity were more profuse in the vicinity of blood vessels, pineal cyst and calcium concretions (corpora arenacea). They displayed a characteristic profile where the pinealocytes formed clusters, widely separated by aggregations of S100 immunoreactive glial cells and their processes took part in the formation of mesh-work in and around each pinealocyte cluster (Figs. 2)

\section{GFAP}

The GFAP immunoreactivity was restricted to the supporting glial cells. the interstitial glial cells, showed a diverse pattern of immunostaining for the intermediate filament proteins (GFAP). At the area of the gland, at which the pinealocytes were evenly distributed, they were surrounded by a network of weak to moderate GFAP immunoreactive glial cell processes, only a relatively few GFAP-positive cell bodies and/or processes were seen in the mar- ginal portions and sub capsular region. The glial cell immunoreactivity to GFAP were conspicuous almost around the large pineal cyst and calcium concretions (corpora arenacea) and at the perivascular spaces. GFAP immunoreactive cells showed similar distribution and morphological characteristics to those of S100reactivity, but their immunoreactivity less dense than S100- immunoreactive cells (figs. 3 ).

\section{Synaptophysin}

Immunolabeling of the pinealocyte marker synaptophysin was intense, especially in pinealocytes at perivascular space that exhibited a very heavy immunolabeling, with no positive staining being observed in the endothelial cells. Pinealocytes exhibited considerable intercellular differences in the densities of immunostaining. Several highly synaptophysin-positive spot of variable size were a conspicuous feature throughout the gland. Immunoractivity to synaptophysin was less dense in the vicinity of pineal cyst and calcium concretion (Corpora arancea), may be due to increases number of interstitial cells and tendency of pinealocyte to form island separated 
by aggregations of intersitial cells, the reaction in pinealocytes was restricted to a small microvesicles. Obviously, these vesicles represent the major site of synaptophysin immunoreactivity in pinealocytes. Nerve terminals displayed strong synaptophysin immunoreactivities. They were particularly numerous in the perivascular spaces (fig. 4).

\section{Discussion}

The location of the donkey pineal gland is similar to that described in other mammals, (Taner 1999; Hendelman, 2000; Dyce et al., 2002; Frandson et al., 2003 and Yildiz et al. 2004; Ozgel et al. 2008 and Carvalho et al. 2009). The shape of the gland was determined to be fusifrom was similar to those reported by Yildiz et al. (2004); Ozgel et al. (2008) and Carvalho et al. (2009). Furthermore the dimensions of the gland were nearly close to reports of Dursum (2002) in cattle, Ozgel et al. (2008) in donkey and Carvalho et al. (2009) in buffalo. The agreement with the previous report, Nasu et al. (1994); Aslan et al. (2003); Yildiz et al. (2004); Ozgel et al. (2008) and Carvalho et al. (2009), in donkey the pineal gland was supplied by the caudal choroidal artery which emanate from the caudal cerebral artery. Furthermore, branches from the artery of corpus callosum which emanate from the rostral cerebral artery that was in consistent with the finding of Carvalho et al. (2009), in donkey. The results obtained indicate the existence of two cell types; interstitial cells, in addition to pinealoblasts, in adult donkey pineal gland. Light microscopy highlighted the resemblance between these cells and the second cell type described in the pineal gland of other species, including mice and rats (Borregon et al. 1993), rabbits (GarciaMaurino and Boya 1992 a), carnivores (Calvo et al. 1990; Boya and Calvo 1993; Boya et al. 1995), horses (Cozzi 1986) and ruminants (Redondo et al. 1996 a; Franco et al. 1997; Regodon et al. 1998 a,b), viscacha (CernudaCernuda et al. 2003). The interstitial Cells displayed characteristics features similar to astrocytes (Cozzi, 1986; Lopez-Munoz et al., 1992 a; Boya and Calvo, 1993). The presence of glial cells in the pineal gland was first demonstrated by impregnation techniques with gold chloridesublimate (Del Rio-Hortega 1932, Scharenberg and Liss 1965). 
Pinealocytes occupied the largest volume of the pineal gland while, interstitial cells were distributed evenly throughout the gland, but they were more abundant around the pineal cyst and corpora arenacea. This finding simulate in part that observed in gerbil and was incontrast to that reported in hamster ( $\mathrm{Li}$ and Welsh 1991). Pineal gland is composed by $95 \%$ pinealocytes (Castro and Munoz 2009).

The globular type of calcified deposits (corpora arenacea) were seen where large amount of interstitial cells were present. Koshy and Vittel ( 2001) reported that, the globular type of calcified deposits were seen where large amount of pineal parenchyma is present and in younger age groups; whereas concentric lamellated type were usually associated with large amounts of glial fibers and in older age. Humbert and Pevet (1995) observed in aging rats two types of calcification by electron microscopic and electron diffraction methods, amorphous and crystalline types. While concretions have been extensively studied in human and gerbil (Krstic and Golaz 1976; Bocchi and Valdre 1993). A new form of biomineralization has been studied in the human pineal gland. It consists of small crystals that are less than $20 \mu \mathrm{m}$ in length. These crystals could be responsible for an electromechanical biological transduction mechanism in the pineal gland due to their structure and piezoelectric properties. Presence of calcified concretions need not reflect a pathological state (Koshy and Vittel 2001).

GFAP is an intermediate filament proteins which are included in the glial filaments. GFAP-containing filaments are present in mature astrocytes of the central nervous system (CNS) (Mokuno et al., 1989). Several immunohistochemical studies using glial cell antigens such as GFAP and S100 protein have suggested a glial nature for the second pineal cell type (Calvo et al., 1988 a). According to their immunocytochemical profile, these cells could be identified as astrocytes (Boya and Calvo 1993). In this respect, immunohistochemistry showed the presence of GFAP and protein S-100 in interstitial cells in non-neoplastic pineal gland in human (Jouvet et al. 1994) and in rat (Takada et al. 2006). 
In the present work, the supporting (interstitial) glial cells, that showed a heterogeneous pattern of immunostaining for the intermediate filament proteins glial fibrillary acidic protein (GFAP). A similar finding was observed in pineal gland of Mongolian gerbil (Redecker et al. 1990) and in sheep (Redondo et al. 2002).

Regarding the distribution and arrangement of the glial cells, they were evenly distributed but they almost conspicuous around the large pineal cyst and corpora arenacea (calcium concretion), where the pinealocytes formed clusters, widely separated by aggregations of GFAP immunoreactive glial cells and their processes as well as around blood vessels. That was similar in part with the finding of Boya and Calvo (1993) and Redondo et al. (2002). Meanwhile, in rat GFAP-positive astrocytes were concentrated at the proximal end of the pineal where the pineal stalk enters the gland (Erik et al. 1993). In this respect, a specialized "basketlike" arrangements of many GFAP-positive astrocytic processes were shown around sheep pinealocytes, while, the human pineals contained scattered astrocytic cell bodies and a moderate number of GFAPpositive astrocytic processes also surrounded pinealocytes, but without the dense basket-like arrangements. In both species GFAP-positive fibers were concentrated at the periphery of pseudolobules and around blood vessels. Rat and guinea pig pineals contained only rare astrocytic cell bodies and few GFAPpositive fibers throughout the glands, however it had a concentration of parallel GFAP-positive fibers at the stalk (Zang et al. 1985). GFAP positive cells presented large somata and long processes. The GFAP positive glial cells were observed peripherally in rat (Castro and Munoz 2009). in contrast to our finding, the pineal has been recognized previously as a unique region of the central nervous system in which a GFAP-negative glial phenotype is maintained in adult mammals (Kofler et al 2002). That was not supported by Li and Welsh (1991), the number of GFAP-immunoreactive astrocytes in the pineal glands of hamsters and gerbils increased with increasing age. Glial fibrillary acidic protein was usually negative in human PTPR papillary tumor of pineal region (Fevre-Montange et al. 2006; Hasselblat et al. 2006; 
Jouvet et al. 2003 and Kuchelmeiste et al. 2006; Levidou et al. 2010).

In the previous literature, The number, location and morphology of these cells suggest they are pineal interstitial cells. This indicates that the interstitial cells are of neuroectodermal origin, possibly macroglial cells themselves. Both ultrastructurally and in terms of antigen expression of GFAP, interstitial cells displayed characteristics similar to those reported for astrocytes (Boya et al. 1995, Cozzi 1986, Zang et al. 1985; Boya and Calvo 1993).

A strong anti S100 immunoreactivity was found in the starshaped glial cells and their processes that were evenly distributed at the pineal gland except at the area of pineal cyst and calcium concretion (corpora aranacia). That was in agreement with the cells exhibiting immunoreactivity for calciumbinding spot 35 protein, identical to S-100-immunoreactive cells, have also been reported to distribute evenly throughout the pineal organ (Yamamoto et al., 1990). Thus, previous and present results indicate that the pineal gland showed regional differences in the degree of cellular association of chief endocrine cells (pinealocytes) with supporting cells and in the expression of marker proteins in supporting cells. Possible significances of these regional differences in pineal gland (Zang et al., 1985; Yamamoto et al., 1990; Lopez-Munoz et al., 1992 a; Borregon et al., 1993, Suzuki and Kachi 1995). In contrast, starshaped cells positively immunostained with anti-S-100 protein were numerous and densely distributed especially in the stalk and the proximal region of the body portion of the pineal gland (Suzuki and Kachi 1995).

In the present study, S100 immunoreactive cells showed similar morphological characteristics to those of GFAP-reactivity, but their immunoreactivity more dense than GFAP-positive cells. While in rat, GFAP immunoreactive cells showed similar morphological characteristics to those of S-100-reactive cells in the stalk and the proximal region of the body portion of the pineal, but in the distal region of the body portion, GFAP-positive cells were not seen (Suzuki and Kachi 1995). 
The present finding revealed GFAP and S100 positive interstitial glial cells were located close to perivascular spaces that was supported by the findings of (Redondo et al. 2002), indicating a possible functional significance of interstitial cells as substrate for the exchange of substances between the pineal parenchyma and the bloodstream (Redondo et al. 1996 a \& b; Franco et al. 1997), which would completed the support function (similar to that of astrocytes in the CNS) traditionally attributed to these cells (López-Muñoz et al.,1992 a ).

In agreement with the previous literature, some neuronal proteins as synaptophysin have been detected in pinealocytes, revealing the neuron-like nature of these cells (Redecker et al. 1990, Coca et al, 1992, Huang et al. 1992, Redecker and Bargsten 1993, Sato et al. 1994 and Takada et al. 2006).

Immunolabeling of the pinealocyte marker synaptophysin immunoexpression was strong especially, in pinealocytes at perivascular space, with no positive staining being observed in the endothelial cells. That was in consistent with the finding of Redondo et al. (2003) in sheep. Pinealocyte cytoplasmic processes display a marked vascular tropism. This affinity, reported elsewhere (Garcia-Maurino and Boya 1992 a \& b, Redondo 1996 a, Regodon et al. 2001) together with the presence of both light and dark vesicles in terminal clubs (Boya et al. 1995, GarciaMaurino and Boya 1992 a \& b , Redondo et al. 1996 a) and of gap junctions (Garcia-Maurino and Boya 1992 a \& b, Redondo 1996 a) advocated that pinealocytes might have certain secretory functions. The presence of all the cytoplasmic structures involved in secretory metabolic activity and the greater degree of development of these structures in pinealocytes, lend morphological support to this hypothetical functionality (Bhatnagar 1992, Redondo et al. 1996 a and Shedpure and Kumar 1995).

Pinealocytes exhibited considerable intercellular differences in the densities of immunostaining. Intercellular differences in staining intensity were only observed among SYN + cells, coinciding with the results obtained by Redecker et al. (1990) and Redondo et al. (2001). 
The immunoractivity to synaptophysin was less dense in the vicinity of the pineal cyst and calcium concretion (corpora arenacea), may be due to increases number of interstitial cells (astrocyte ), tendency of pinealocyte to form small clusters also the reaction in pinealocytes was restricted to a small microvesicles. Thus supporting the existence of the regional morphological and biochemical differences found in the rat and bovine pineal gland (Sato et al., 1994; Hira et al., 1998; Martinez-Soriano et al., 2002 b). in contrast, distribution and localization of synaptophysin-positive cells were homogeneous (Redondo et al. 2003).

The intercellular differences in the grades of synaptophysin immunostaining might, therefore, reflect different states of a specific cellular activity. The presence of synaptophysin in pinealocytes of the normal pineal, give emphasis to the paraneuronal character of these cells (Coca et al. 1992; Redecker and Bargsten 1993 and Sato et al. 1995; Feng et al. 1998). By the consecutive semithin-thin section technique, they could be identified as processes of pinealocytes, filled with accumulations of small clear ves- icles, similar vesicles have been ascribed a role in the secretory activity of the gland, and/or in the transport of calcium ( Redecker et al. 1990).

Nerve terminals displayed strong synaptophysin immunoreactivities. They were particularly numerous in the perivascular spaces. That was supported by the finding of Arendt (1995) the endocrine activity of the pineal gland depends on the neurological innervation.

Total lack of synaptophysin expression, is a consistent feature and diagnostic criterion for pineal parenchymal tumors in both humans and animals (McGavin et al. 2007 and Mena et al. 1995). Immunohistochemical analysis showed that the neoplastic glial cells were negative for synaptophysin as well as glial fibrillary acidic protein (GFAP) ( Levidou et al. 2010)

\section{References}

Arendt, J. (1995): Melatonin and the mammalian pineal gland. London: Chapman \& Hall; 1995. pp. 6-49.

Aslan, K. S.; Ozcan, G.; Akosy, G.; Kurtul, I. and Dursum, N. (2003): Arterial vascu- 
larization of pineal gland in the fetus of zavot-bred cattle. Anat. Histol. Embryol. 32: 124-125.

Bhatnagar, KP. (1992): The ultra structure of mammalian pinealocytes: a systematic investigation. Microsc Res Tech. 21 (2): p. $85-115$. Bancroft, J.D.; Stevens, A.;

Turner, DR. (1996): Theory and Practice of Histological Techniques, 4th ed. Churchill Livingstone, London, Toronto, 1996.

Bocchi, G.; and Valdre, G.

(1993): Physical, chemical and mineralogical characterization of carbonatehydroxyapatite concretions of the human pineal gland. Journal of Inorganic Biochemistry, vol. 49, pp. 209-220.

Borregon, A.; Boya, J.; Calvo,

J.L.; and Lopez-Munoz, F. (1993): Immunohistochemical study of the pineal glial cells in the postnatal development of the rat pineal gland. J Pineal Res 14: 78-83

Boya, J. and Calvo, J.L. (1993):

Immunohistochemical study of the pineal astrocytes in the postnatal development of the cat and dog pineal gland. J Pineal Res 15: 13-20

Boya, J.; Calvo, J.L. and Ranca no, D. (1995): Structure of the pineal gland in the adult cat. J. Pineal Res., 18, 112-118.

Cagnacci, A. (1996): Melatonin in relation to physiology in adult humans. J Pineal Res; 21:200-213.

Calvo, J. L.; Boya, J. and Garcia, Maurino, J.E. (1988): UItrastructure of the pineal gland in the adult dog. J. Pineal Res., , 5, 479-487.

Calvo, J. L.; Boya, J. and Garcia Maurino, J.E. (1990): Postnatal development of the dog pineal gland : Electron microscopy. J. Pineal Res., 8, 245-254.

Carvalho, A. F.; Ambrosio, C. E.; Miglino, M. A.; Mancanares, C. A. and Blazquez F. J. (2009): Macro-Microscopical aspects of the buffalo (Bubalisbubalis Linnaeus, 1758) pineal gland. Biotema, 22(2): 127-135.

Castro, A.E. and Munoz, E.M. (2009): Cell types in the adult rat pineal gland. Acta Microscopica, Vol. 18, Supp. C, 2009

Cernuda-Cernuda, R.; Piezzi, 
R.S.; Domnguez, S. and Alvarez-Uria, M. (2003): Cell populations in the pineal gland of the viscacha (Lagostomus maximus). Seasonal variations. Histol Histopathol 18 (3): 827-836.

Coca, S.; Vaquero, J.; Escandon, J.; Moreno, M.; Peralba, $\mathrm{J}$. and Rodriguez, J. (1992): Immunohistochmical characterization of pineocytomas

Clin.Neuropathol. 11 (6), 298-303.

Cozzi, B. (1986): Cell types in the pineal gland of the horse : an ultrastructural and immuno-cytochemical study. Anat. Rec., 216, 165-174.

Cozzi, B. and Ferrandi, B. (1984): Fine structure and histochemistry of the equine pineal gland with special reference to the possible functional role of the electron-dense intrapinealocyte bodies. Clin. Vet., 107, 337-346.

Del Rio-Hortega, P. (1932): Pine al gland. In Cytology and cellular pathology of the nervous system. Edited by: Penfield W. New York: Hoeber: 2:635-703.

Dursum, N. (2002): Veteriner an tomi II, 8. Baski., Medisan Yayinevi, Ankara, pp: 224

Dyce, K. M.; Sack, W. O. and Wensing, C. J. G. (2002): Textbook of veterinary anatomy .3rd Ed. Saunders. An Imprint of Elsivier Sci. Philadelphia, pp: 213.

Erik, B. Pedersen; Linda M. Fox; Anthony J. Castro and John A. McNulty (1993): Immunocytochemical and electron-microscopic characterization of macrophage/microglia cells and expression of class II major histocompatibility complex in the pineal gland of the rat. Cell and Tissue Research Volume 272, Number 2, 257-265, DOI:

10.1007/BF00302731

Feng, X.L.; Usui, H.; Fujita, T.; Ichikawa, T.; Katagiri, T.; Washiyama, K. and Kumanishi, T. (1998): Postnatal development changes in NSE and NNE mRNA expression in the rat pineal gland : in situ hybridization histochemistry. J. Pineal Res., 24 (2), 108-116.

Fevre-Montange, M.; Hasselblatt, M.; Figarella-Branger, D.; Chauveinc, L.; Champier, 
J.; Saint-Pierre G.; CouIon, A.; Paulus, W.; Fauchon $F$, Jouvet A. (2006): Prognosis and histopathologic features in papillary tumors of the pineal region: a retrospective multicenter study of 31 cases. $\mathrm{J}$ Neuropathol Exp Neurol 65:1004-1011.

Franco, A.; Regodon, S.; Masot, A.J. and Redondo, E. (1997): A combined immuno-histochemical and electronmicroscopic study of the second cell type in the developing sheep pineal gland. J. Pineal Res., 22, 130-136.

Frandson, R. D.; Lee Wilke, W. and Fails, A. D. (2003): Anatomy and physiology of farm animals. 6th Ed. Lippiocott Williams and Wilins, Philadelphia, $p p$ 138-200.

Garcia-Maurino, J.E. and Boya, J. (1992 a): Postnatal maturation of the parenchymal cell types in the rabbit pineal gland. Histol. Histopathol., 7 (1): 75-81.

Garcia-Maurino, J.E. and Boya, J. (1992 b): Postnatal development of the rabbit pineal gland. A light- and electron microscopic study. Acta Anat., 143, 19-26.

Hasselblatt, M.; Blumcke, I.; Jeibmann, A.; Rickert, C. H.; Jouvet, A.; Van De Nes, J. A. P.; Kuchelmeister, K.; Brunn, A.; FevreMontange, $M$. and Paulus, W.(2006): Immunohistochemical profile and chromosomal imbalances in papillary tumours of the pineal region. Neuropathol Appl Neurobiol 32: 278-283.

Hendelman, W.J. (2000): Atlas of functional neuroanatomy. CRC Press, New York, pp:24.

Hira, Y.; Sakai, Y. and Matsushi ma, S.(1998): Quantitative light microscopic study on the heterogeneity in the superficial pineal gland of the rat. Anat. Rec, 250 (1), 80-94.

Huang, S.K.; Klein, D.C. and Korf, H.W. (1992): Immunocytochemical demonstration of rodopsin, s-antigen and neuron-specific proteins in the human pineal gland. Cell Tissue Res., 267 (3), 493498.

Humbert, W. and Pevet, P. 
(1995): Calcium concretions in the pineal gland of aged rats: an ultrastructural and microanalytical study of their biogenesis: Cell \& Tissue Research 279(3): 565-73.

Koshy, S. and Vettivel S.K. (2001): Varying Appearances of Calcification in Human Pineal Gland: A Light Microscopic Study. J Anat. Soc. India 50(1) 1718

Kofler, B.; Bulleyment, A.; Hum phries, A. and Carter, D. (2002): Id-1 expression defines a subset of vimentin / S-100ß-positive, GFAP-negative astrocytes in the adult rat pineal gland. Histochemical J. vol. 34, pp. 167-171

Krstic, R. and Golaz, J. (1976): Ultrastructural and X-ray microprobe comparison of gerbil and human pineal acervuli, pp. 507-578.

Kumar, G. L. and Rudbeck, L. (2009): Education Guide: Immunohistochemical staining methods (5th Ed.). Dako North America, Carpinteria, California.

Kuchelmeister, K.; Hu"gens-

Penzel, M.; Jo" dicke, A.; Schachenmayr,
(2006): Papillary tumour of the pineal region: histodiagnostic considerations. Neuropathol Appl Neurobiol 32: 203-208.

Kus, I.; Sarsilmaz, M.; Ozen, O. A.; Turkoglu, A. O.; Pekmez, $H_{\text {.; }}$ Songur, A. and Kelestimur, H. (2004): Light and electron microscopic examination of pineal gland in rats exposed to constant light and constant darkness. Neuroendocrinology Letters Nos.1/2 Feb-Apr Vol. 25, 102-108

Jouvet, A.; Fèvre-Montange, M.; Besançon, R.; Derrington, E.; Saint-Pierre, G.; Belin, M. F.; Pialat, J.; Lapras, C. (1994): Structural and ultrastructural characteristics of human pineal gland, and pineal parenchymal tumors. Acta Neuropathologica Vol.: 88 , Issue: 4 : 334-348.

Jouvet, A,.; Fauchon, F.; Liberski, P.; Saint-Pierre, G.; Didier-Bazes, M.; Heitzmann, A.; Belin, M.F.; FevreMontagne, M.: (2003): Papillary tumor of the pineal region. Am J Surg Pathol 27: $505-512$.

Levidou, G., Korkolopoulou, P., 
Agrogiannis,G., Paidakakos,N., Bouramas, D., Patsouris, E. (2010): Lowgrade oligodendroglioma of the pineal gland: a case report and review of the literature. Diagnostic $\mathrm{Pa}-$ thology. 5:59

Li, K.; Welsh, M. G.(1991): Santigen and glial fibrillary acidic protein immunoreactivity in the in situ pineal gland of hamster and gerbil and in pineal grafts: developmental expression of pinealocyte and glial markers. Am J Anat. 192(4):510-22.

Lopez-Munoz, F.; Boya, J.; Cal vo, J. L. and Marin, F. (1992): Immunohistochemical localization of glial fibrilliary acidic protein (GFAP) in rat pineal stalk astrocyte. HistolHistopath 7 (4): 643-646.

Martinez-Soriano, F.; Ruiz-

Torner, A.; Armananzas, E. and Valverde Navarro A. A. (2002) :Influence of light/dark, seasonal and lunar cycles on the nuclear size of the pinealocytes of the rat. Histol. Histopathol. 17, 205-212.

McGavin, M. D.; Zachary, J. F. eds. (2007): Nervous system. In: Pathologic basis of veterinary disease, 4th ed., p. 739. Mosby, Philadelphia, PA.

Mena, H.; Rushing, E. J.; Ribas, J.L. ; Delahunt, B.; McCarthy, W.F. (1995): Tumors of pineal parenchymal cells: a correlation of histological features, including nucleolar organizer regions, with survival in 35 cases. Hum Pathol 26 (1): 20-30.

Mokuno, K.; Kamholz, J.; Beh rman, T.; Black, C.; Sessa, M.; Feinstein, D. and Lee, V. (1989): Neuronal modulation of Schwann cell glial fibrillary acidic protein (GFAP). J Neur. osci Res 23 (4): 396-405

Nasu, T. Nakai, M. and Muraka mi, N. (1994): Vascularization of the pineal gland in cow. J. Vet. Med. Sci. 56: 1185-1186.

Ozgel, O.; Dursum, N. and Oto, C. (2008): Morphology and arterial vascularization of the pineal gland in donkeys. Meycyna Weterynaryjna, 63: 15611563.

Redecker, P. and Bargsten, G. 
(1993): Synaptophysin a common constituent of presumptive secretory microvesicles in the mammalian pinealocyte : a study of rat and gerbil pineal glands. J. Neurosci. Res., 34 (1), 79-96.

Redecker, P.; Grube, D. and Jahn, R. (1990): Immunohistochemical localization of synaptophysin (p38) in the pineal gland of Mongolian gerbil (Meriones unguiculatus). Anat. Embryol., 181 (5), 433-440

Redondo, E. A.; Franco, A.; Masot, J.; and Regodón, S. (2002): Ultrastructural and immunocytochemical characterization of interstitial cells in pre- and postnatal developing sheep pineal gland. Eur. J. Histochem. 45: 249258.

Redondo, E., A., Masot J, Fran co A. and Regodón S. (2001): Immunohistochemical and ultrastructural characterization of pinealocytes in sheep prenatal development. Revue Méd.Vét., 2001, $152,7,535-544$

Redondo, E.; Franco, A. and
Regodon, S. (1996 a): Prenatal development of the sheep pineal gland : An ultrastructural study. J. Pineal Res., , 21 (3), 140148.

Redondo, E.; Franco, A.; Lopez,

C. and Regodon, S. (1996

b): The presence of supportive cells in the prenatal development of the sheep pineal gland. The Intern. J. Develop. Biol. (Suppl.), 1, 211-212

Redondo, E.; Regodon, S.; Fran co, A.; Masot, J.; Gzquez, A.; and Cardinali, D. P. (2003): Day-night changes in plasma melatonin levels, synaptophysin expression and ultrastructural properties of pinealocytes in developing female sheep under natural long and short photoperiods. Histol Histopathol. 18: 333-342

Regodon, S.; Franco, A.; Masot, A.J. and Redondo, E. (1998 a): Structure of the ovine pineal gland during prenatal development. J. Pineal Res., 25, 229-239.

Regodon, S.; Franco, A.;

Gazquez, A. and Redondo, E. (1998 b): Presence of pigment in the ovine 
pineal gland during embryonic development. Histol. Histopathol., 13, 147154.

Regodon, S.; Franco, A.; Masot, A.J. and Redondo, E. (2001): Postnatal maturation of parenchymal cell types in sheep pineal gland : an ultrastructural and immuno-electronmicroscopic study. Revue Méd. Vét., 2001, 152, 4, 325-333.

Sakai Y., Hira Y. and Matsushi ma S. (1996): Regional differences in the pineal gland of the cotton rat, Sigmodon hispidus: Light, electron microscopic, and immunohistochemical observation. J. Pineal Res. , 20 (3), 125-137.

Sato, T.; Kaneko, M.; Ekataksin, W. and Wake, K. (1995): Expression of neuronspecific enolase in the pineal organ of the domestic fowl during posthatching development. Cell Tissue Res., 279 (1), 25-36.

Sato, T.; Kaneko, M.; Fujieda, H.; Dedguchi, T. and Wake, K. (1994): Analysis of heterogeinity within bovine pineal gland by im- munohistochemitry and in situ hybridization. Cell Tissue Res., 277 (2), 201209.

Scharenberg, K.; Liss, S. (1965):

The histologic structure of the human pineal body. Prog Brain Res, 10:193217.

Shedpure M. and Kumar A.

(1995) : The pineal gland : structural and functional diversity. Ind. J. Exp. Biol., 33, 625-640.

Suzuki, T. and Kachi, T. (1995): Immunohistochemical Studies on Supporting Cells in the Adrenal Medulla and Pineal Gland of Adult Rat, Especially on S-100 Protein, Glial Fibrillary Acidic Protein and Vimentin. Acta Anat Nippon $70:$ 130-139.

Takada, Y.; Fariss, N.; Muller, M.; Bush, A.R.; Rushing, E. J.; Sieving A. (2006): Retinoschisin expression and localization in rodent and human pineal and consequences of mouse RS1 gene knockout. Mol Vision 12: 1108-1116.

Taner, D. (1999): Fonksiyonel noroanatomi. Ikinci baski. METU Press Ankara, pp: 201. 
Yamamoto, M.; Kondo, H.; Yam akuni, T. and Takahashi, Y. (1990) Expression of immunoreactivity for Cabinding protein, spot 35 in the interstitial cells of the rat pineal organ. Histochem J 22: 4-10.

Yildiz, D. Gultiken, U. G. and Bo lat, D. (2004): Arterial supply od the pineal gland of Akkaraman sheep. Acta. Vet. Hung, 52: 1-6.

Zang, X.; Nilaver, G.; Stein, B.M.; Fetell, M.R. and Duffy, P.E. (1985): Immunocytochemistry of pineal astrocytes: species differences and functional implications. J Neuropathol Exp Neurol 44: 486-495 
Table 1: Identity, sources, and working dilutions of primary and secondary antibodies.

\begin{tabular}{|c|c|c|c|c|c|c|c|}
\hline \multirow[t]{2}{*}{ againest } & \multicolumn{4}{|c|}{ Primary antibodies } & \multicolumn{3}{|c|}{ Secondary antibodies } \\
\hline & Type & Origin & Source & $\begin{array}{l}\text { Dilu- } \\
\text { tion }\end{array}$ & Type & Source & $\begin{array}{l}\text { Dilu- } \\
\text { tion }\end{array}$ \\
\hline S100 & $\begin{array}{l}\text { Monocol- } \\
\text { onal anti } \\
\text { human } \\
\text { S100 co- } \\
\text { lon N1573 }\end{array}$ & Mouse & $\begin{array}{l}\text { Dako } \\
\text { Cytoma- } \\
\text { tion, } \\
\text { Glostrup, } \\
\text { Denmark }\end{array}$ & 1:50 & $\begin{array}{l}\text { poly- } \\
\text { clonal } \\
\text { rabbit } \\
\text { anti- } \\
\text { cow }\end{array}$ & $\begin{array}{l}\text { Dako } \\
\text { Cytoma- } \\
\text { tion, } \\
\text { Glostrup, } \\
\text { Denmark }\end{array}$ & $1: 300$ \\
\hline GFAP & $\begin{array}{l}\text { Monocol- } \\
\text { onal anti } \\
\text { human } \\
\text { GFAP } \\
\text { colon } \\
\text { M0761 }\end{array}$ & Mouse & $\begin{array}{l}\text { Dako } \\
\text { Cytoma- } \\
\text { tion, } \\
\text { Glostrup, } \\
\text { Denmark }\end{array}$ & $1: 50$ & $\begin{array}{l}\text { poly- } \\
\text { clonal } \\
\text { rabbit } \\
\text { anti- } \\
\text { cow }\end{array}$ & $\begin{array}{l}\text { Dako } \\
\text { Cytoma- } \\
\text { tion, } \\
\text { Glostrup, } \\
\text { Denmark }\end{array}$ & $1: 300$ \\
\hline $\begin{array}{l}\text { Synapto- } \\
\text { physin }\end{array}$ & $\begin{array}{l}\text { Monocol- } \\
\text { onal anti } \\
\text { human } \\
\text { synapto- } \\
\text { physin } \\
\text { colon } \\
\text { N1566 }\end{array}$ & Rabbit & $\begin{array}{l}\text { Dako } \\
\text { Cytoma- } \\
\text { tion, } \\
\text { Glostrup, } \\
\text { Denmark }\end{array}$ & 1:100 & $\begin{array}{l}\text { poly- } \\
\text { clonal } \\
\text { rabbit } \\
\text { anti- } \\
\text { cow }\end{array}$ & $\begin{array}{l}\text { Dako } \\
\text { Cytoma- } \\
\text { tion, } \\
\text { Glostrup, } \\
\text { Denmark }\end{array}$ & $1: 300$ \\
\hline
\end{tabular}



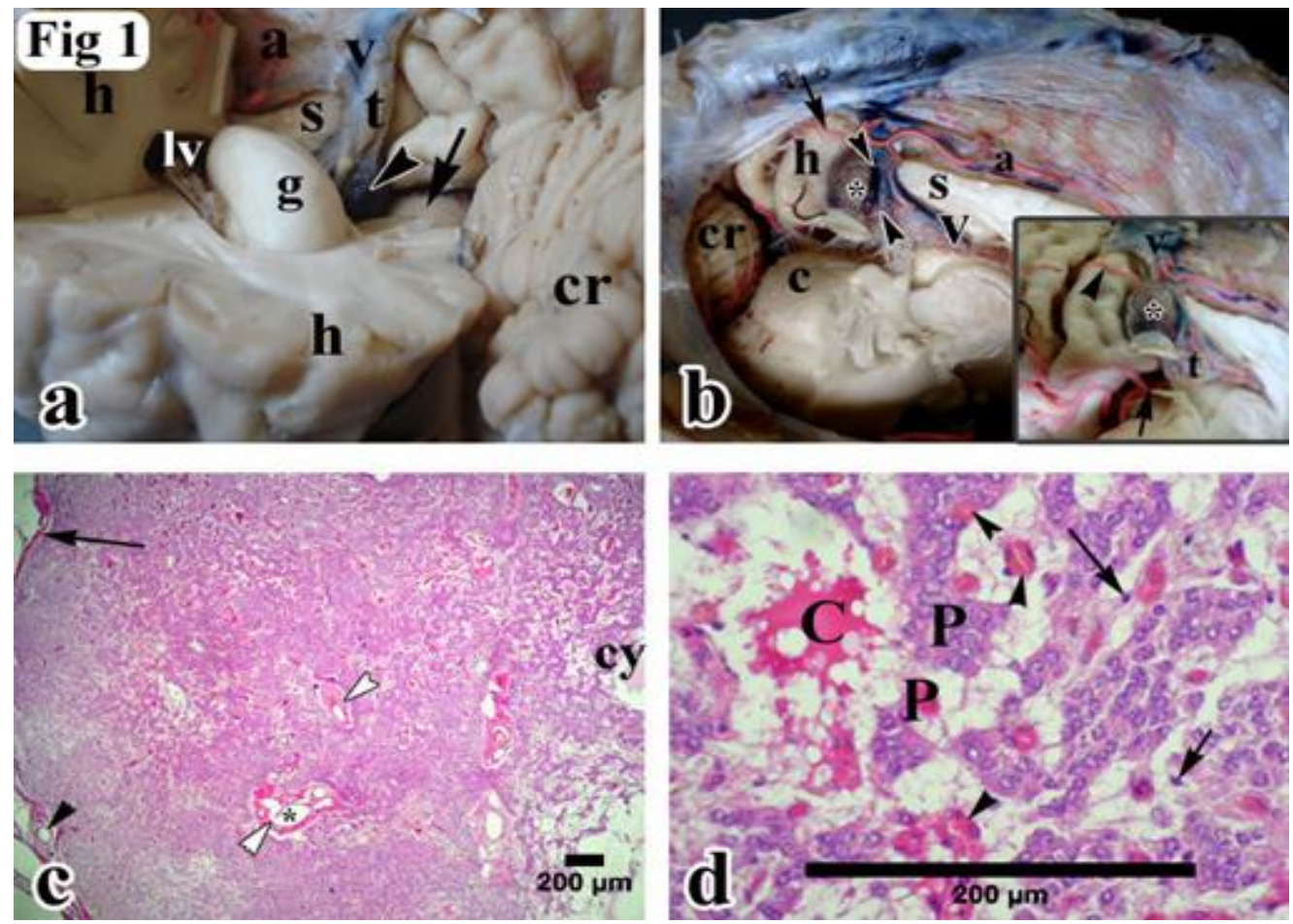

Fig (1):

a: Dorsolateral view of the brain of donkey after removal of the caudal part of the left cerebral hemisphere, showing, the pineal body (arrow head), splenium of the corpus callosum $(\mathrm{s})$, telachoroidea of the third ventricle $(\mathrm{t})$, cerebral vein $(\mathrm{v})$, artery of corpus callosum (a), rostral colliculi (arrow) hippocampus $(\mathrm{g})$, cerebral hemisphere $(\mathrm{h})$, Cerebellum (cr) lateral ventricle (Iv).

b: Saggittal section in the brain of donkey, showing, the pineal body (asterisk), splenium of the corpus callosum (s), telachoroidea of the third ventricle (t), cerebral vein (v), rostral colliculi (c), cerebral hemisphere (h), Cerebellum (cr), pineal branches (arrow heads) derived from artery of corpus callosum (a), pineal branch from caudal choroidal artery (arrow). Intersect: pineal gland (asterisk), pineal branch (arrow head) from the caudal choroidal artery (arrow).

c: H \& E stained pineal gland with relatively thick connective tissue capsule (arrow), with relatively large blood vessels (arrow head), incomplete septa (open arrow head) with large blood vessels (asterisk) and pineal cyst (cy) in pineal parenchyma. Bar $=200 \mu \mathrm{m}$.

d: $H$ \& $E$ stained pineal gland, pinealocyte formed clusters $(P)$ separated by aggregations of glial cells and their processes (arrow) at the area of calcium concretion copora arenacea (C), blood capillaries (arrow head) in between pinealocyte and glial cells. Bar $=200 \mu \mathrm{m}$. 

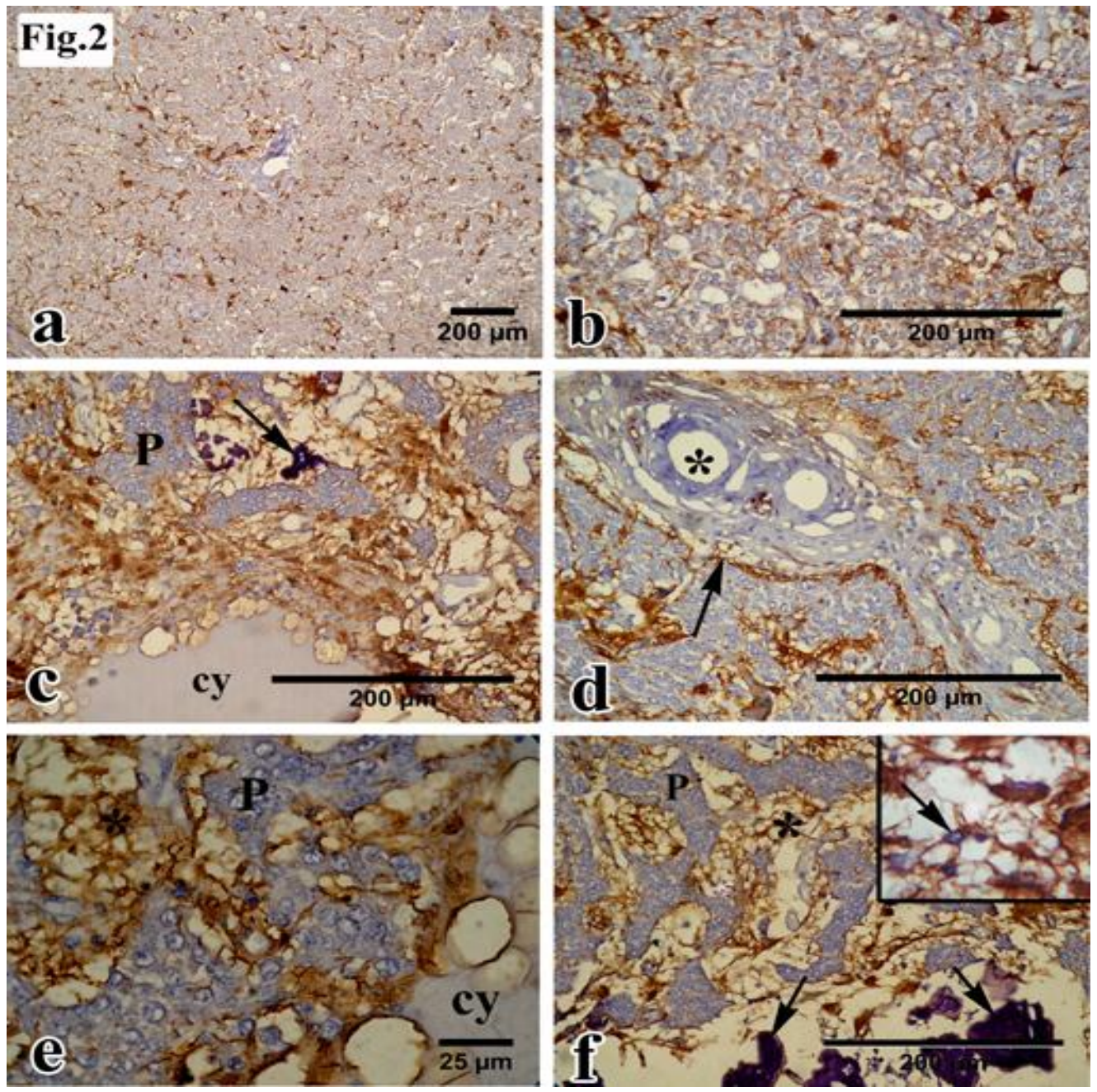

J. Vet. Anat. 


\section{Fig (2): Immunolocalization of S100 protein in adult donkey pineal gland.}

a: Strong anti S100 immunoreactivity in the star-shaped glial cells and their processes, that were evenly distributed. Bar $=200 \mu \mathrm{m}$.

b: Magnification of (a) S100 immunoreactive glial cells and their processes forming a meshwork around pinealocyte Bar $=200 \mu \mathrm{m}$.

c: Pinealocytesfroming clusters $(P)$ separated by aggregations of strong anti S100 immunoreactive glial cells and their processes at the vicinity of pineal cyst (cy) and the corpora arancea (arrow). Bar= $200 \mu \mathrm{m}$.

d: Localization of anti S100 immunoreactivty (arrow) at the vicinity of blood vessels (astrisk). Bar $=200 \mu \mathrm{m}$.

e: Magnification of (c) at the vicinity of pineal cyst (cy), showing, pinealocytes clusters $(P)$ separated by anti S100 strong immunoreactive glial cells meshwork (asterisk). Bar $=25 \mu \mathrm{m}$. f: Pinealocytes clusters $(P)$ separated by anti $\$ 100$ strong immunoreactive glial cells meshwork (asterisk) at the region of corpora arenacea (arrows). Bar $=200 \mu \mathrm{m}$. Intersect: magnification of

f: showing glial cells and their strong immunoreactive cells to anti S100 protein. 

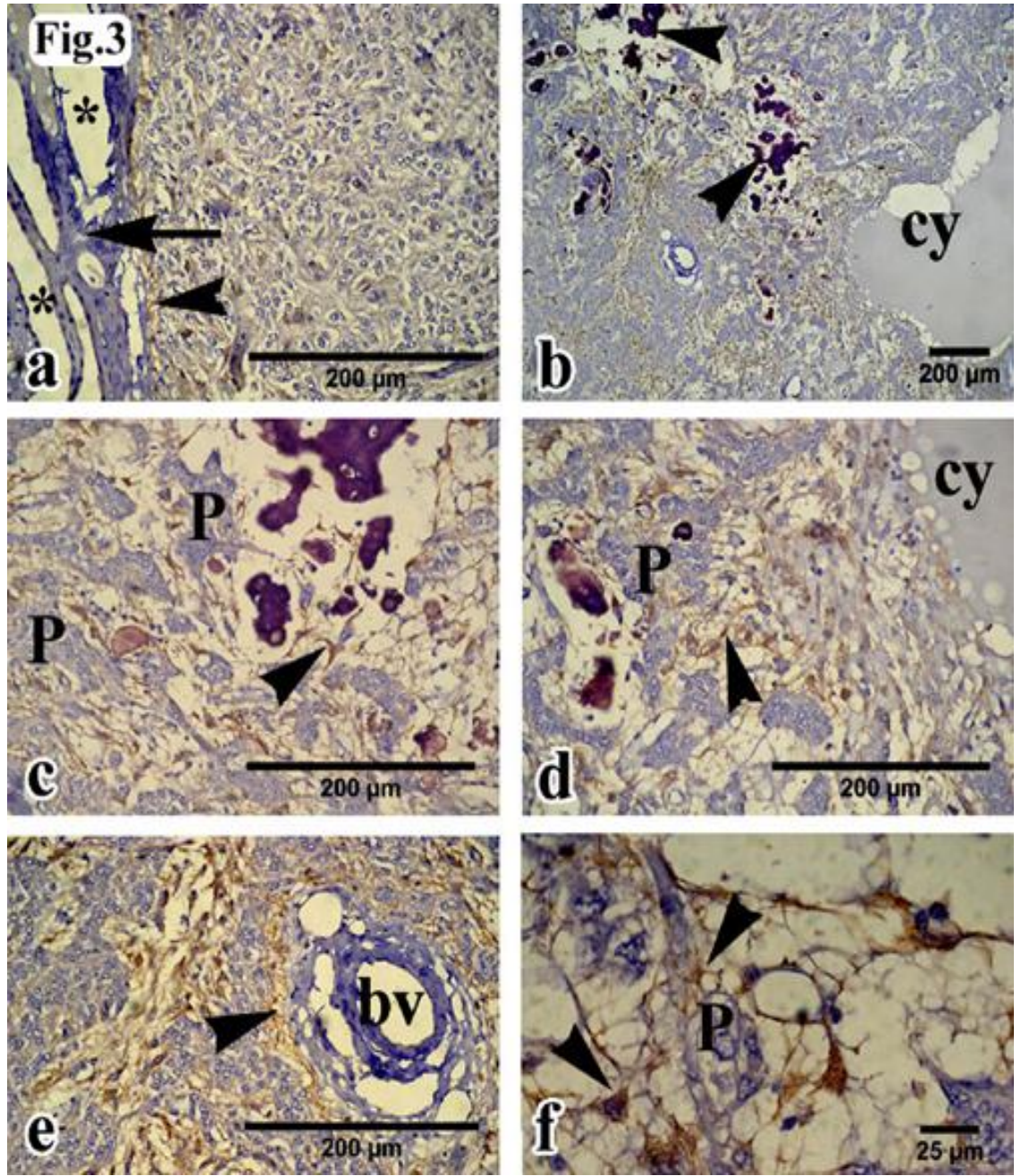

J. Vet. Anat. 
Fig (3): Immunohistochemical staining for glial fibrilary acidic protein (GFAP) in adult donkey pineal gland.

a: Immunoreactivity of GFAP is located underneath the pineal gland capsule (arrow head). The pinealocytes were evenly distributed superficially, the GFAP immunoreactivity in between is weak to moderate, the pineal gland capsule (arrow), blood vessels (asterisk). Bar $=200 \mu \mathrm{m}$.

b: GFAP immunoreactivity was more obvious at the vicinity of pineal cyst (cy) and corpora arenacea (arrow heads). Bar $=200 \mu \mathrm{m}$.

c: Magnification of (b) showing, pinealocytes froming clusters $(P)$ separated aggregations of GFAP immunoreactive glial cells and their processes. Bar $=200$ $\mu \mathrm{m}$.

d: Magnification of (b) at the vicinity of pineal cyst (cy), showing, pinealocyte sfroming clusters $(P)$ separated aggregations of GFAP immunoreactive glial cells and their processes. $\mathrm{Bar}=200 \mu \mathrm{m}$.

e: Localization of GFAP immunoreactivty (arrow head) at the vicinity of blood vessels (bv). Bar $=200 \mu \mathrm{m}$. f: GFAP immunoreactive glial cells and their processes (arrow head) forming a meshwork around pinealocyte $(P)$. bar $=25 \mu \mathrm{m}$. 

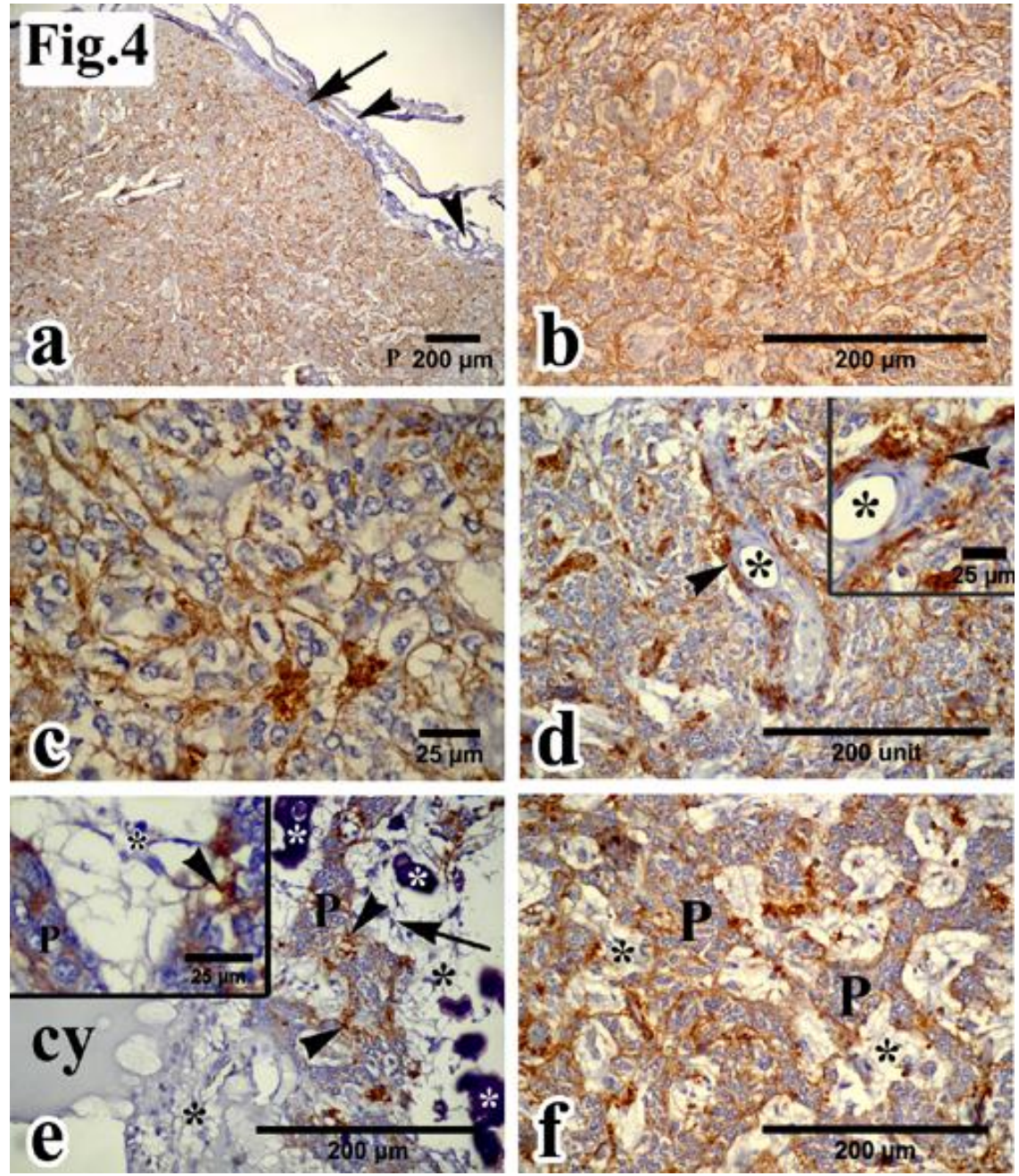

J. Vet. Anat. 
Fig (4): Synaptophysin immunoreactivity in pinealocytes in adult donkey pineal gland.

a: Strong synaptophysin immunoreactivity in pinealocytes, that were evenly distributed superficially, under the pineal capsule (arrow), many blood vessels (arrow heads). Bar $=200 \mu \mathrm{m}$.

b: magnification of (a), synaptophysin immunoreactivity of pinealocytes and their processes. Bar $=200 \mu \mathrm{m}$.

c: Pinealocytes and their processes immunoreactivity to synaptophysin $(P)$ glial cells (arrow), nerve ending (arrow head). Bar $=25 \mu \mathrm{m}$.

d: Localization of synaptophysin in pinealocytes at perivascular space (arrow head) blood vessels (astrisk). Bar $=200 \mu \mathrm{m}$. Intersect: Magnification of blood vessels (asterisk) and the synaptophysin immunoreactivity in perivascular space (arrow head). Bar $=25 \mu \mathrm{m}$.

e: Synaptophysin immunoreactivity (arrow heads) was restricted to the clusters of pinealocytes $(P)$ at the region of corpora arenacea (asterisk) and pineal cyst (cy) the glial cells and their processes were negative to synaptophysin (black asterisk). Bar $=200 \mu \mathrm{m}$. Intersect: Magnification of (e), synaptophysin immunoreactions (arrow head), pinealocyte clusters $(P)$, glial cells and their processes were negative (asterisk), pineal cyst (cy), corpora arancea (arrow). Bar $=200 \mu \mathrm{m}$. Intersect: Magnification showing pinealocyte $(P)$, negative glial cell processes to synaptophysin (astrisk) Bar $=25 \mu \mathrm{m}$.

f: Pinealocytes form clusters $(P)$ exhibit a strong immunoreactivity to synaptophysin, glial cells and their processes (asterisk) appeared negative . Bar $=200 \mu \mathrm{m}$. 